\title{
SPECIFIC ASPECTS OF MITHRAISM IN ETRURIA AND UMBRIA
}

\begin{abstract}
Summary: The Mithraic evidence in Etruria and Umbria - VII and VI Regiones - presents some particular features of great interest, not only because they contribute to enlarging our knowledge regarding the extent of the diffusion of Mithraism in these regions, but also as regards the general study of the cult itself and the comprehension of certain facets of the cultic implantation patterns within the religious communities.

The epigraphic corpus of Mithraism in Umbria provides valuable information concerning some grades of initiation and Mithraic priesthood, highlighting the specificity of this religion. The importance of such information transcends what we know about the local level, by revealing details about the functioning of the cult in general, especially regarding the degree of Leo and some variants of the priesthood, which are poorly documented elsewhere in the Roman Empire.

In addition, the discovery of Mithraea, Mithraic images and other archaeological evidence in Etruria and Umbria provides a picture that shows an important spread of the worship in the private context, i.e., both domus and villae, with examples as relevant as Vulci and Spoletium. Further ahead, the prevalence of astral components in the material evidence also suggests a strong preference among local devotees of Mithras of higher social status for the cosmological aspects of their religion.
\end{abstract}

Key words: Mithraism, Etruria, Umbria, Private Mithraea, Mithraic Leones, Leonteum

The Mithraic archaeological catalogue of the ancient Augustan regions of Etruria and Umbria - the VII and VI Regiones - shows a noteworthy spread of the cult in these territories and reveals some specific features of special interest, and their study will expand our knowledge of some of the characteristics of Mithraism itself and of certain facets of its implementation methods.

In Etruria, a large dispersion of testimonies of this cult prevailed - although it was mostly concentrated in the southern area and, principally, around the Via Cassia and the Via Cornelia, ${ }^{1}$ whereas in Umbria its spread was more extensive in the southern area, with a focus along the Via Flaminia.

\footnotetext{
${ }^{1}$ RUBIO RIVERA, R.: Difusión, asimilación e interacción de los cultos mistéricos orientales en Etruria y Umbría. Madrid 1991 (http://eprints.ucm.es/2320), 192-206 and 309.

${ }^{2}$ RUBIO: Difusión (n. 1) 207-221 and 309; RUBIO RIVERA, R.: Consideraciones en torno al mitraísmo en Umbría. In GASPARINI, V. (a cura di): Vestigia [PAwB 55]. Stuttgart 2016, 407-419.
} 
In the regio Etruria, three archaeologically documented Mithraea were known: two in urban areas and one in a suburban zone. The Mithraeum of Cosa is located in the forum, re-using a semi-subterranean space in the substructiones of the Curia. ${ }^{3}$ The Mithraeum of $\mathrm{Vulci}^{4}$ (discovered in 1975) is installed in a domus abutting the eastern flank of the Domus del Criptoportico. ${ }^{5}$ The spelaeum of Sutrium ${ }^{6}$ was dug into the rock and located in the suburban area, near to the urban wall, to the amphitheatre and to the Via Cassia. Another Mithraeum, also dug into the rock, was added to them in 1997 in the Visentium territory, near Capodimonte (Poggio, Falchetto, Capodimonte, VT), although no archaeological intervention has been carried out yet. $^{7}$

To this list we must also add several recent findings which have transformed the outlook on Mithraism in the region. In 2009, the archaeological excavations of Portus Pisanus brought to light a Mithraeum installed in a former storehouse. ${ }^{8}$ At the same time, in 2014, the illegal plundering of the Tarquinia tauroctony, after its recovery by the carabinieri, allowed us to locate its original archaeological context and to confirm its ascription to the context of a domus. ${ }^{9}$

These five archaeologically documented Mithraea ${ }^{10}$ are part of a larger set of Mithraic sanctuaries which we have various kinds of indirect evidence of. For example,

${ }^{3}$ Brown, F. E. ET AL.: Cosa III. The Buildings of the Forum. Pennsylvania 1993, 245; FENTRESS, E. ET AL.: Cosa V. An Intermittent Town. Excavations 1991-1997. Michigan 2003, 63 and 65-66; and HenriQues, J. C.: The Mithraeum at Cosa in this volume, DOI: 10.1556/068.2018.58.1-4.10.

${ }^{4}$ SGUBIni MoretTi, A. M.: Nota preliminare su un mitreo scoperto a Vulci. In BiANCHI, V.: Mysteria Mithrae [EPRO 80]. Leiden 1979, 259-276; RUBIO: Difusión (n. 1) 478-485.

${ }^{5}$ CeluzzA, M. G. (a cura di): Vulci e il suo territorio nelle collezioni del Museo archeologico e d'arte della Maremma. Milano 2000, 28.

${ }^{6}$ Cumont, F.: Mithra en Étrurie. In PARIBENI, R. (ed.): Scritti in onore di Bartolomeo Nogara. Raccolti in occasione del suo 70 anno. Città del Vaticano 1937, 97-100, fig. XI 1; VERMASEREN, M. J.: Corpus Inscriptionum et Monumentorum Religionis Mithriacae [CIMRM]. The Hague 1956, 653; RUBIO: Difusión (n. 1) 467-469. A marble relief with tauroctony has also been located $(63 \times 107 \mathrm{~cm})$ in an unidentified place in Sutrium (conserved in the Museo Nazionale Romano. Terme di Diocleziano), which $\mathrm{Cu}-$ mont regards as coming from the Mithraeum: CumonT, F.: Textes et Monuments figurés relatifs aux Mystères de Mithra [MMM]. Brussels 1896-1898, II 487, 98bis (see also: CIMRM 654; RUBIO: Difusión [n. 1] 470). An archival document from the early 20th century could confirm the origin of the relief: http://www.infosutri.it/index.php/la-chiesa-di-san-michele-arcangelo.

${ }^{7}$ Biamonte, G.: Uno spelaeum mitraico nel territorio dell'antica Visentium presso Capodimonte sul lago di Bolsena. SMSR 63 (1997) 23-36.

${ }^{8}$ DuCCI, S.: Portus Pisanus. Torna alla luce l'antica vocazione marinara di Livorno. Comune Notizie 68, luglio-settembre (2009) 5-11; GENOVESI, S.: Nuove evidenze per il culto di Mitra dall'area di Portus Pisanus/S. Stefano ai Lupi. Materiali per Populonia 10 (2011) 277-288. The Mithraeum would have reused the storehouse in the 3rd century, installing the usual side benches - it had an altar in the central corridor -, and remained in use until the beginning of the 5th century AD.

9 Operazione "Mitra Tauroctono" in http://palazzo.quirinale.it/mostre/2015_tesori/doc/Operazione Mitra_Tauroctono.pdf; Il mitreo della civita di Tarquinia in http://palazzo.quirinale.it/mostre/2015_tesori/ doc/mitreo

Civita_Tarquinia.pdf. SCAPATICCI, M. G.: The Discovery of the Mithras Statue of Tarquinia, in this volume, $\overline{\mathrm{DOI}}$ : 10.1556/068.2018.58.1-4.2.

${ }^{10}$ Difficulties persist in assuming the recent interpretation as a Mithraeum, disseminated through the local digital press, of a subterranean chamber in Acqua Claudia (Anguillara Sabazia). 
the votive inscription found in the vicinity of Ficulle presupposes the existence of a Mithraic spelaeum. ${ }^{11}$ In this case, despite the imprecise information regarding the exact location of the find, it may be assumed to come from a villa, situated close to the river Paglia, where this Mithraeum would have been located, instead of Volsinii, to which it has traditionally been ascribed. ${ }^{12}$ Furthermore, the marble tauroctony from $\mathrm{Veii}^{13}$ - recovered in 2009 by the Guardia di Finanza - was the cult image of a Mithraeum because of its large dimensions $(154 \times 160 \mathrm{~cm})$.

In addition, there are more Mithraic findings from Etruria, among them two tauroctonies which have been found in context: the excellent two-sided Mithraic relief from Fiano Romano, ${ }^{14}$ which seems to have pertained to a villa, and the one from Soriano nel Cimino, which was also discovered in the context of a Roman villa, within a subterranean space. ${ }^{15}$ Other remains attest to the presence of Mithraism in the region, ${ }^{16}$ in Torrita Tiberina, ${ }^{17}$ Vicus Matrini (Capranica), ${ }^{18}$ Caere, ${ }^{19}$ Rusellae, ${ }^{20}$

${ }^{11}$ CIL XI 2684: Tiberius Claudius Thermodon dedicates Soli Invicto Mitrhae (sic) a spelaeum cum signis et ara ceterisque. Currently, it is conserved in the church of S. Maria Vecchia of Ficulle.

${ }^{12}$ CumONT: MMM II 122, 161; CIMRM 660; RUBIO: Difusión (n. 1) 475-476; ClAUSS, M.: The Roman Cult of Mithras: The God and His Mysteries. New York 2000, 43.

${ }^{13}$ Archeologia, a Roma scultura dio Mitra recuperata da Gdf. Antikitera.net, 23 giugno 2009 (http://www.antikitera.net/news.asp?ID=4396); La Guardia di Finanza di Roma recupera un importante rilievo marmoreo del dio Mitra che uccide il toro (https://www.beniculturali.it/mibac/export/MiBAC/sitoMiBAC/Contenuti/Eventi/EventiInEvidenza/visualizza_asset.html_1600480668.html); FuSCO, U.: New Reliefs from Veii and Mithraic Reliefs from Etruria (Regio VII): Iconography, Chronology and Archaeological Context, in this volume, DOI: 10.1556/068.2018.58.1-4.5.

${ }^{14}$ Found in a "stronghold" with collapsed tiles. Preserved in the Louvre Museum. The marbled relief $(62 \times 67 \mathrm{~cm})$ represents on one side the tauroctony and on the other a Mithraic banquet scene. CumONT, F.: Un bas-relief mithriaque du Louvre. RA 25 (1946) 183-195, figs 1-2; CIMRM 641, figs 179-180; RUBIO: Difusión (n.1) 459-460.

${ }^{15}$ Marble tauroctony $(58 \times 62 \mathrm{~cm})$, found to the north of Mount Cimino, amongst the remains of a subterranean room built in opus caementicium, belonging to a villa. CUMONT: Mithra (n. 6) 102, fig. 2; CIMRM 657, fig. 184; RUBIO: Difusión (n. 1) 466.

${ }^{16}$ Some Mithraic materials are of uncertain origin, like the peculiar depiction of the tauroctonous Mithras on the chest of a bust of Jupiter Sabazios in bronze, which would probably have been found in Volsinii (CuMONT: Mithra [n. 6] 96; CIMRM 659a, fig. 185; RuBIO: Difusión [n. 1] 476-477), as in the large part of those preserved in Florence: see n. 27 below.

${ }^{17}$ Statue of Dadophorus (h: $65 \mathrm{~cm}$ ) with the inscription Hymnus Inbicto. CIL XI 3865; CUMONT: MMM II 105 and 162; CIMRM 645-646, II 32; RUBIO: Difusión (n. 1) 471-472.

${ }^{18}$ Bas-relief of Peperino with the tauroctony and an inscription in the bottom-left corner mentioning the dedicator L. Avillius Rufinus (CIL XI 3320; CUMONT: Mithra [n. 6] 101, fig. XI 2; CIMRM 656). It is reused on the façade of the casale della Capannace (Capranica), located next to via Cassia, between Vetralla and Capranica. This spot has traditionally been considered as the site of the mansio of Vicus Matrini. It has been suggested the possible provenance of this tauroctony from the Mithraeum of Sutrium (M. ANDREUSSI in EAA [1997], s.v. Vicus Matrini), although it could come from the Roman remains of the surroundings of the casale or from one of the villae known in the area.

${ }^{19}$ The finding of a schematic tauroctony recorded in the inside of the hypogaeum of Clepsina, in the urban area of Caere, has been presented by Fabio Colivicchi in the Symposium Peregrinum 2016 hold in Tarquinia, see: https:/www.universityresearch.ca/projects/find-projects/mithras-in-the-mundusmithras-in-caere/.

${ }^{20}$ Sculptural fragment of Mithras which would belong to a tauroctony $(60 \times 40 \mathrm{~cm})$, found in Rusellae and preserved in the museum in Grosseto. CUMONT: MMM II 122, 99; RUBIO: Difusión (n. 1) 465 . 


\author{
Montalcino, ${ }^{21}$ Asciano, ${ }^{22}$ Colle Arsiccio (Magione), ${ }^{23}$ Arretium, ${ }^{24}$ Cavriglia, $^{25}$ Pisa $^{26}$ \\ and Florentia. ${ }^{27}$
}

Concerning Umbria, the only archaeologically documented Mithraeum is that of Spoletium, excavated in 1878 by Fabio Gori ${ }^{28}$ within the structures of a suburban Roman villa, in the proximity of the Via Flaminia and of the city itself. ${ }^{29}$

Recently the identification of two possible Mithraea has been proposed, both dug in the rock: one under the Basilica of S. Valentino, in Terni, and the other in the Christian catacombs of Grotta Traiana, in Villa San Faustino, which supposedly reused

${ }^{21}$ Small tabula ansata $(7 \times 12 \mathrm{~cm})$ from a probable dedication to Mithras in its dies natalis. CIL XI 2596; RUBIO: Difusión (n. 1) 461-462.

${ }^{22}$ Marbled sculpture of tauroctonous Mithras $(42 \times 47 \mathrm{~cm})$, aquired by Cumont and supposedly originating from Asciano. Preserved in the Academia Belgica in Rome. CUMONT: Mithra (n. 6) 102-103, pl. XII 1; CIMRM 662, fig. 187; RUBIO: Difusión (n. 1) 455-456.

${ }^{23}$ Fragments of a tauroctony and other cultual objects in terracotta found in the 1980s: MORANDINI, F.: Una testimonianza del culto mitraico a Colle Arsiccio di Magione (PG). RdA 30 (2006) 77-91, pl. 21-32.

${ }^{24}$ Small cippus with votive inscription, found reused in the wall of a house near the church of San Niccolò in Arezzo (dedicated by Myron servus). CIL XI 1821; CUMONT: MMM II 128, 204; CIMRM 658; RUBIO: Difusión (n. 1) 454.

${ }^{25}$ Lower half of tauroctony, discovered in the 1970s in Pieve di San Giovanni Battista of Cavriglia, among the architectural remains of a Roman settlement, probably a villa, next to the via Cassia Adrianea: TRACCHI, A.: Dal Chianti al Valdarno. Ricognizioni archeologiche in Etruria 3 (1978) 73, pl. 57.3; Bocci Pacini, P. - Nocentini Sbolci, S.: Museo Nazionale Archeologico di Arezzo. Catalogo delle sculture romane. Roma 1983, 28.

${ }^{26}$ Marble tauroctony relief $(44 \times 55 \mathrm{~cm})$ which was found reused in a private house in Via l'Acciughe after being preserved in the cementery in Pisa. CUMONT: MMM II 257-258, 100, fig. 95; CIMRM 663; RUBIO: Difusión (n. 1) 463-464.

${ }^{27}$ The group of Mithraic materials preserved in Florence do not have known origins, but generally they are attributed to ancient Florentia: in any case, although if some of them may have gathered in Florentine collections originating from other places in the region or elsewhere, it is probable that the cult of Mithras would have spread among the inhabitants, given the importance of some oriental cults in the city - especially that of Isis. The Mithraic materials are the following: a fragment of a sculpture depicting a tauroctonous Mithras (37×43cm; CUMONT: MMM II 259, 103; CIMRM 664; RUBIO: Difusión [n. 1] 486-487); Leontocephalic statue $(115 \times 35 \mathrm{~cm}$; CUMONT: MMM II 258-259, 101, fig. 96; CIMRM 665, fig. 188; RuBio: Difusión (n. 1) 487-488; BoRTOLin, R.: Il Leontocefalo dei Misteri mitriaci. Padova 2012, 206-207, 14, fig. 14); the lower part of a saxigenus Mithras statue $(72 \times 43 \mathrm{~cm}$; CUMONT: MMM II 259, 102, fig. 420; CIMRM 666, figs 189-190; RUBIO: Difusión [n. 1] 488-489); a possible head of Mithras (CUMONT: MMM I 182; CIMRM 667, II 33; RUBIO: Difusión [n. 1] 489-490); a relief with tauroctony $(68 \times 50 \mathrm{~cm}$; CIMRM 668; RUBIO: Difusión [n. 1] 490-491); and a red jasper gem with an engraved tauroctony, other Mithraic symbols, seven stars and seven inscribed words (Cumont: MMM II 450-451, fig. 402a; CIMRM 2354, fig 653; RUBIO: Difusión [n. 1] 492-493).

${ }^{28}$ F. GORI in Archivio storico-artistico della città e provincia di Roma II (1877) 367-368, (187879) 55-62, 252-256; CoOTE, H. CH.: On the Mithraeum at Spoleto. Archaeologia or Miscellaneous Tracts Relating to Antiquity 47 (1882) 205-208, pl. 7; CUMONT: MMM II 255-256, 97, figs 89-90; CIMRM 673, fig. 192; RuBio: Difusión (n. 1) 522-537; BASTiAnelli, G.: Il mitreo di Spoleto. Bollettino della Deputazione di Storia Patria per l'Umbria 104 (2007) 27-53.

${ }^{29}$ GORI, F.: Ville e insediamenti rustici di età romana in Umbria. Perugia 1983, 186, 192; RUBIO: Difusión (n. 1) 522-523, 527; BASTIANELLI (n. 28) 30-31. 
a pre-existing Mithraeum. ${ }^{30}$ Nevertheless, the lack of Mithraic finds and other characteristic components of the spelaea suggests that their identification is still doubtful.

The rest of the Umbrian Mithraea are known through their mention in inscriptions, like that of Montoro, ${ }^{31}$ mentioning the reconstruction of a Mithraeum following the destruction caused by an earthquake. The reference to the permission granted by the ordo decurionum, ${ }^{32}$ indicates that this Mithraeum was located in an urban site, possibly Carsulae. ${ }^{33}$

The Leonteum mentioned in the inscription of San Gemini ${ }^{34}$ should be added; it was erected in an urban area and on public land - probably in the nearby Carsulae too -, as shown by the specific permit granted by the decuriones and the formula $l$ (oco) d(ato) d(ecreto) d(ecurionum) ${ }^{35}$

Without any doubt, the important Mithraic community attested by the epigraphy of Sentinum ${ }^{36}$ and a fragmentary tauroctony ${ }^{37}$ confirms the existence of at least one Mithraeum in this city. ${ }^{38}$

Other findings from the region, such as altars or Mithraic reliefs, allow us to infer the existence of spaces dedicated to the cult of Mithras. Thus, in Ocriculum we are able to conjecture the existence of a Mithraeum in a suburban villa, because an inscription bearing the dedication by a Pater of a signum Invicti Mitrhe (sic) and a Mithraic bas-relief with the tauroctony and various scenes of the myth of Mithras was

${ }^{30}$ SiSANI, S.: Umbria. Marche [Guide archeologiche Laterza]. Roma-Bari 2006, 180.

${ }^{31}$ Ciotti, U.: Due iscrizioni mitriache inedite. In BoER, M. B. DE - EDRIDGE T. A. (éd.): Hommages à Maarten J. Vermaseren I. Leiden 1978, 233-246, here 234-236; AE 1996 (1999) 601. Luni marble slab, fractured in the upper right corner where the text is lost; deposited in the castle of Montoro.

32 The mention of the authorisation by the ordo decurionum is not frequent in Mithraic epigraphy, precisely because of the absence of canonical public temples in the Mithraic religion. Instead, it appears in the inscription of San Gemini, using, as in the text of Montoro, the formula ex permissu sanctissimi ordinis decurionum: Also see nn. 35 and 63 below.

${ }^{33}$ This city is mentioned in the inscription. Regarding this question see RUBIO: Difusión (n. 1) 501-502; RUBIO: Consideraciones (n. 2) 411.

${ }^{34}$ CiOTTi (n. 31) 233-239 and fig. 28; RuBiO: Difusión (n. 1) 510-512; RUBIO RIVERA, R.: El leonteum de la inscripción de San Gemini: sede de los leones mitraicos. In MANGAS MANJARRES, J. Alvar, J. (coord.): Homenaje a J.M a . Blázquez: de Oriente a Occidente. Vol. III. Madrid 1993, 319-329.

${ }^{35}$ In particular, this formula appears only on another Mithraic inscription, from Mediolanum $(C I L$ V 5796; CUMONT: MMM II 191).

${ }^{36}$ CIL XI 5735-5737; CUMONT: MMM II 120-122, 156-158; CIMRM 687-689; RUBIO: Difusión (n. 1) 514-520.

${ }^{37}$ RAmelli, C.: Monumenti mitriaci di Sentino, antico municipio romano. Fermo 1853, 15-16, fig. I 1; CUMONT: MMM II 257, 98; CIMRM 685; RUBIO: Difusión (n. 1) 520-521. In addition, it is also worth recalling the well-known mosaic of Aion (in the Glyptothek of Munich), surrounded by the circle with the zodiacal signs and with possible links with Mithraism, found in a villa near Sassoferrato (Sentinum). CUMONT: MMM II 419-120, 298, fig. 350.

${ }^{38}$ In this sense, C. Ramelli stated that the Mithraic inscriptions, found together with the tauroctony and other constructive materials in the mid-19th century on the property of the Romagnoli family, suggest the existence of a Mithraeum, which, however, was not located: RAMELLI (n. 37) 30-31, fig. II. He also speculated that another Mithraeum there might be under the Monastery next to the Church of S. Croce di Tripozzo: RAMELLI (n. 37) 31-32. In any case, the large and active Mithraic community of Sentinum could have used more than one Mithraeum. 
discovered in the same context. ${ }^{39}$ Also, in southern Umbria, in a context which has been ascribed to the villa rustica of Colle d'Oro in the Terni area, in the Interamna Nahars territory, a white marbled bas-relief representing Mithras tauroctonus was found at the end of the 19 th century. ${ }^{40}$

In the vicinity of Montefalco, the upper part of an altar with concise votive inscription - Soli Invicto - has been found re-used in a building. ${ }^{41}$ This does not guarantee the location of the Mithraic sanctuary in which this altar was originally placed, although its provenance from Trebiae or its territory is plausible. Precisely to this city should be ascribed a fragmentary sculpture of a bull, interpreted as a part of a tauroctony. $^{42}$

Finally, to the north of Umbria, the cult is attested in the port city of Fanum Fortunae, where in 1949 a cippus with a votive inscription was discovered, dedicated to Deo Soli Invicto, together with a Mithraic relief - with a representation of Chronos or a leontocephalic Aion - and other fragments from sculptures, ${ }^{43}$ in a context of destruction, probably associated with the intervention of Christians who would have broken and buried these and other manifestations of the pagan cult. ${ }^{44}$ These finds corroborate with the existence of at least one Mithraeum in the city.

${ }^{39}$ PIETRANGELI, C.: Otricoli. Roma 1978, 32-34. This inscribed plaque and relief are ascribed by Pietrangeli to the finds of the pontifical excavations at Ocriculum in 1778: PIETRANGELI 32-34. Regarding inscription see: CUMONT: MMM II 101, 42; CIMRM 625; PIETRANGELI 34, fig. 26; RUBIO: Difusión (n. 1) 505-506. On the relief $(75 \times 50 \mathrm{~cm})$ : CUMONT: $M M M$ II 236, 74; CIMRM 556, fig. 159; PIETRANGELI 32-34, fig. 25; RUBIO: Difusión (n. 1) 507-509. In addition, from Ocriculum, but from a different, uknown, archaeological context - in 1879 - comes an inscribed fragment on which only appears Mitrha (sic): CuMONT: MMM II 122, 160; CIMRM 684; RUBIO: Difusión (n. 1) 506.

${ }^{40}$ CUMONT: $M M M$ II 253-254, 96 and fig. 88; CIMRM 670 and fig. 191; RUBIO: Difusión (n. 1) 497-498. The relief $(39 \times 51 \mathrm{~cm})$ presents some specific elements of interest like a group of flaming arae, set among trees, at the top of the cave which surround Mithras, as well as a series of vases, aligned at the bottom (see RUBIO: Difusión [n. 1] 498).

${ }^{41}$ CIL XI 4755; CuMONT: MMM II 128, 203a; CIMRM 683; RUBIO: Difusión (n. 1) 499. The altar was reused in the stairway of the "casa colonica" Meloni, in the Castle of Fratta, located in the area of the ancient Trebiae. It was later removed, being currently placed in Poreta di Spoleto: "Qui trovasi tuttora, in località Sodicci, nel giardino della casa Benedetti del Rio" see http://www.protrevi.com/protrevi/ epigr02.asp\#1.

42 Prosperi VAlenti, G.: Una scultura mitriaca di Trevi in una lettera inedita di Ridolfino Venuti. In CASAle, V. (a cura di): Scritti di Archeologia e Storia dell'Arte in onore di Carlo Pietrangeli. Roma 1996, 101-108, figs 110-115.

${ }^{43}$ G. ANNIBALDI in Fasti Archeologici 1949 (1951) 3838; RuBIO: Difusión (n. 1) 495-496. The cippus and the relief with the interesting representation of Aion (identified as the leontocephalic Chronos by Annibaldi, although the upper part of the figure has not been preserved) was discovered in the reconstruction works of the Palazzo Vescovile of Fano, in Via Rainiero, together with fragments of other statues; amongst them was a possible Dea Triformis, which also could be associated with the Mithraic context: RuBIO: Difusión (n. 1) 496.

${ }^{44}$ Some of the sculptural remains belong to Egyptian divinities. Hence the mixture of cults as a whole, their fragmentary state and the fact that they were buried in the same place, point to the action of Christianity in its effort to erase the remains of Pagan worship, and especially those of the mysteric religions: RUBIO: Difusión (n. 1) 496. 
One of the relevant features of Mithraism in Etruria and Umbria is the private aspect of the majority of Mithraea. Many of them were found in an urban context, having been installed in suburban domus and villae.

Thus, in Etruria, the mentioned Mithraea of Vulci and Tarquinia are linked to domus, and in Umbria, the Mithraeum of Spoleto, is in a suburban villa, to which other finds that seem to ascribe to villae would have to be added. In this regard, I consider that the installation of Mithraea in private contexts was a characteristic form of the spread of Mithraism, because a mysteric cult excluded public manifestations and fit perfectly for the multiplication mechanisms of the communities of the faithful. Furthermore, the architectural characteristics of the spelaeum itself could find easy locations in some of the residential areas. ${ }^{45}$

The same mechanisms would correspond to the presence of Mithraea in villae in rural areas, as a form of the implementation of Mithraic communities in private contexts. $^{46}$ In this sense, and since they could belong to a villa, decontextualized Mithraic materials found in a territory could hardly be ascribed to the closest city, as often occurred in literature. Thus, for example, was the case of the inscription of Ficulle, which was attributed to the city of Volsinii. ${ }^{47}$ Moreover, the excellent relief of Fiano Romano, in spite of the few references to the context of its discovery, was supposed to have belonged to the Mithraeum of a villa.

On the other hand, it should be noticed how these private Mithraea, when they belonged to the elites, presented a decorative and even architectural richness and they usually emphasized the teleological and cosmological contents of the Mithras cult, as occurred in the Mithraeum of Spoletium. ${ }^{48}$ Concurrently, the private context probably allowed the gathering of a select Mithraic community, ${ }^{49}$ which brought together

${ }^{45}$ RUBIO RIVERA, R.: Mitreos en domus y villae. ARYS 6 (2003-2005) 129-138. On private Mithraea in Rome see: CoARELli, F.: Topografia mitriaca di Roma. In Mysteria Mithrae (n. 4) 69-79; GrIfFITH, A. B.: Mithraism in the private and public lives of 4th-c. Senators in Rome. Electronic Journal of Mithraic Studies 1 (2000) http://www.uhu.es/ejms/Papers/Volume1Papers/ABGMS.DOC; BJøRNEBYE, J.: The cult of Mithras in fourth century Rome. Bergen 2007, 67-80.

${ }^{46}$ RUBIO: Mitreos (n. 45) 136. The location of Mithraea in villae, as much suburban as rural, are but variants of the same phenomenon, in which intervening factors similar to those of the spelaea installed in urban domus, principally related with the inherent nature of Mithraism, as much for the character of the cult itself - exempt from public manifestations -, as for the limited number of members of a community and the multiplications mechanism of the Mithraea (RUBIO: Mitreos [n. 45] 133-134, 137).

${ }^{47}$ See n. 12 above.

${ }^{48}$ In this Mithraeum, the profusion of the use of marble, not only in sculptural elements and other objects but also in the interior decoration of the Mithraeum, highlights the richness which was wished to be imposed on the sanctuary. At the same time, the relevance of the more cosmological aspect of Mithraism is confirmed, by the representation of the planets and the fragment with the zodiac signs. All this suggests that the Mithraeum was built and decorated according to the preference of the villa owner, giving it a sumptuousness according to its status and the most cosmogonic dimension prevailing in the manifestations and religious expressions of the cult dedicated to Mithras.

${ }^{49}$ One of the most eloquent known example is the Mithraeum of S. Silvestro in Capite of the senatorial family of Olimpii (4th C) - considered a private Mithraeum: A. B. GRIFFITH (n. 45) - in which the found epigraphical documentation (CIMRM 399-405; GALLO, D.: Il mitreo di San Silvestro in Capite. In Mysteria Mithrae [n. 4] 231-242) has allowed the verification of how the degree of Pater passes from father to son in three generations. 
devotees from the same social group as that of the owner and with a high cultural level, so that they could share the most refined and philosophical aspects of Mithraism. $^{50}$

The epigraphic corpus of Mithraism from Umbria provides valuable details concerning some grades of initiation and the Mithraic priesthood, allowing us to know the specificity of this cult in the Umbrian context and revealing details unknown or scarcely documented in the rest of the Roman Empire about the enactement of the cult.

From various sources we know the seven grades of Mithraic initiation, ${ }^{51}$ but we do not have the precise information about the mechanisms of the internal organisation of Mithraic communities. Indeed, there are many unknowns that persist in this regard, up to the point that controversies and interpretations have occurred over the Mithraic grades. ${ }^{52}$ Therefore the evidence of many Leones and Patres in Umbria are especially interesting.

Exceptional are the testimonies for the grade of Leo, the fourth on the initiation scale, in Umbria, as much for the number of attested cases, as for the significance throughout the Empire, since specific mentions of the grades are scarce, but the grades of Pater and Leo are the most represented. Therefore, the number of Umbrian testimonies is extraordinary compared with other regions of Italy - or of the Empire: thus, of the 41 Leones in the Empire, documented by Clauss, those corresponding to Umbria represent a quarter, ${ }^{53}$ being only comparable with the number of cases attested in Rome.

Clauss considers this number of Leones to be casual, or would reflect a local peculiarity of the Mithras cult. ${ }^{55}$ In my opinion, this is instead due to the intensity of the spread of the cult in the Umbrian area, because of its proximity to Rome (through

${ }^{50}$ RUBiO: Mitreos (n. 45) 136-137.

${ }^{51}$ The seven grades are listed by Hieronym. Epist. 107. 2. Also partially mentioned by other authors, notably Porph. De abst. 4. 16; Porph. De antro 15-16, coinciding with the more explicit archaeological findings, such as the famous mosaic of the Mithraeum of Felicissimus at Ostia (BECCATI, G.: Scavi di Ostia. II: I Mitrei. Roma 1954, 105-110), in which the attributes of the seven grades are represented, or the paintings of the Mithraeum of Santa Prisca (VERMASEREN, M. J. - VAN ESSEN, C. C.: The Excavations in the Mithraeum of the Church of Santa Prisca in Rome. Leiden 1965, 165-177), in one of whose walls with mural paintings the invocations to all the grades are recorded (preceded by the Mithraic term nama).

${ }^{52}$ In this sense, it is worth mentioning the controversy arisen by Clauss's attribution of a supposed priestly character to all Mithraic grades, as by his peculiar idea that most devotees would only be initiated in one grade (CLAUSS: The Roman Cult [n. 12] 131-133). This totally speculative proposal has been refuted by numerous specialists: see, among others: GORDON, R. L.: Who worshipped Mithras? Journal of Roman Archaeology 7 (1994) 459-474, here 465; GORDON, R. L.: Ritual and Hierarchy in the Mysteries of Mithras. ARYS 4 (2005) 245-274; ALVAR, J.: Los Misterios. Religiones "orientales" en el Imperio Romano. Barcelona 2001, 274-275. More recently ChaluPA, A.: Seven Mithraic Grades: An Initiatory or Priestly Hierarchy? Religio 16.2 (2008) 177-201, following the arguments of Gordon.

${ }^{53}$ Clauss, M.: Die sieben Grade des Mithras-Kultes. ZPE 82 (1990) 183-194, here 185-187; Clauss, M.: Cultores Mithrae. Die Anhängerschaft des Mithras-Kultes. Stuttgart 1992, 46-47, 55; CLAuSs: The Roman Cult (n. 12) 136.

${ }^{54}$ Clauss: The Roman Cult (n. 12) 136. See also, MAstrocinQue, A.: The Mysteries of Mithras: A Different Account. Tübingen 2017, 17, regarding the frequency of mentions to the Leones in the sources.

${ }^{55}$ Clauss: The Roman Cult (n. 12) 136. 
the Via Flaminia). However, it should also be underlined that nine of them proceed from a unique inscription, that of San Gemini, which considerably increases the total number of Leones registered in Umbria. ${ }^{56}$

Furthermore, one of the three inscriptions of Sentinun confirming the existence of a large local community of Mithraists, mentions a Pater Leonum between the cultores Dei Solis Invicti Mithrae. ${ }^{57}$ The title Pater Leonum is of uncertain interpretation and only appears in this text. This figure is generally interpreted as a Pater, whose tutelage would have been superimposed on the initiates of the grade of Leo ${ }^{58}$ although it could also be a way of referring to one who held superior authority with the group of Leones, a primus inter pares, like the Pater Patrum, ${ }^{59}$ documented in nine inscriptions throughout the Empire and considered a Pater with superior authority over other Patres. $^{60}$

Yet an epigraphic unicum, also linked to the grade of Leo, appears in the inscription from San Gemini: the Leonteum. ${ }^{61}$ On the nature of this space, various suggestions have been put forward, although they coincide in that it would be a space which would specifically serve as the seat of the Leones. ${ }^{62}$ In my mind, the information which the inscription provides seems to refer more to an independent building than to an annex of a Mithraeum. ${ }^{63}$ Such a building could have the same characteristics of interior architecture as a Mithraeum. In this sense, the case of the Mithraeum of Santa Prisca is suggestive: a good part of its wall paintings and inscriptions have a special connection with degree of Leo. ${ }^{64}$

A new testimony of the term Leonteum, in its Greek equivalent Leonteion, recurs in the Berlin papyrus published by Brashear, being considered a fragment of a possible Mithraic catechism. ${ }^{65}$ The text consists of a sequence of questions and answers and seems to be part of an initiation, precisely, to the grade of Leo. Although this testimony of the term hardly provides information about the Leonteion's nature, at least it confirms that it is a place, since it appears to have been mentioned in response to a fragmentary question which starts by saying "Where...?" ${ }^{66}$ In this regard,

${ }^{56}$ RUBiO: Consideraciones (n. 2) 409.

${ }_{58}^{57}$ CIL XI 5736; Cumont: MMM II 122, 156; CIMRM 687; RUBIO: Difusión (n. 1) 515-520.

${ }^{58}$ Aloe SpADA, C.: Il leo nella gerarchia dei gradi mitriaci. In Mysteria Mithrae (n. 4) 645; RUBIO: Difusión (n. 1) 283-286.

${ }^{59}$ RUBiO: Difusión (n. 1) 284-285; RUBIO: Consideraciones (n. 2) 408-409. Also a preeminent position plays a Leo in a votive inscription from Rome (CIMRM 367) such as Leo Antistes.

${ }^{60}$ CIMRM 57, 336, 369, 378, 400-403.

${ }^{61}$ See n. 34 above.

${ }^{62}$ For a summary of the approaches on the theme and a new proposal in an article specifically on the Leonteum, see: RUBIO: El leonteum (n. 34) 319-329. MASTROCINQUE: The Mysteries (n. 54) 17 quotes a quite imprecise passage in Porphyry (de Abst. 4. 16), where is said "that among the Mithraists there were participants called Leones and servants called Corvi-Coraces, and this assertion dovetails with the name Leonteum in certains Mithraea".

${ }^{63}$ As the formulas a solo and l(oco) d(ato) d(ecreto) d(ecurionum) seem to indicate. RUBIO: El leonteum (n. 34) 321.

${ }_{64}^{64}$ As I have pointed out several years ago: RUBIO: El leonteum (n. 34) 328. Vienna 1992.

${ }^{65}$ BRASHEAR, W.: A Mithraic Catechism from Egypt (P. Berol. 21196) [Tyche Supplementband I].

${ }^{66}$ BRASHEAR (n. 65) 27-28. RUBIO: El leonteum (n. 34) 329. 
the Leonteum could be the place where they celebrated the initiations to the grade of Leo and, depending on the facilities available to the Mithraic community or the group of Mithraic communities of a city - such as the association of cultores of Sentinum -, it could be an annex of the Mithraeum or a specific space suitable to that effect. In addition, we have to think that it could also be a way of generating new communities by gathering in a new seat of worship a group of initiates who would have already reached the fourth grade - a context in which the Pater Leonum makes sense.

Another noteworthy aspect of Mithraism in Umbria is the numerous references to the priesthood, something that is not very frequent in the Mithraic epigraphy, principally because the initiation hierarchy itself provided the higher grades, especially to the seventh, that of Pater, with the priestly competence. In this respect, the existence of priests generated arguments about its correlation with the hierarchy of grades and about the functions that they would carry out. ${ }^{67}$ In this sense, the documentation of several examples, - of various origin - in which explicit reference is made to the dual condition of Pater et sacerdos, ${ }^{68}$ implies that they may have had different tasks, at least in some communities. ${ }^{69}$

In Umbrian territory, only the votive inscription of Ocriculum $^{70}$ refers with certainty to the grade of Pater, in an act of offering a signum to Mithras, a characteristic concern of the members of this highest level of the initiatory hierarchy, who often acted as benefactors of the cultic community, especially when defraying Mithraic reliefs and other elements of the sacred furniture. ${ }^{71}$ The other allusion to a Pater is precisely the aforementioned Pater Leonum, recorded in the inscription of the Mithraic cultores of Sentinum. Instead, three Umbrian testimonies allude to the Mithraic priesthood without any explicit indication of the grade and with some peculiarities.

Thus, the inscription from San Gemini is an especially relevant case, because, in addition to qualifying Egnatius Reparatus ${ }^{72}$ as sacerdos legitimus et collator, it is said that he performed the initiation of Leones, thus providing specific information of one of the functions which had been entrusted to him in his ministry. ${ }^{73}$ In the above

${ }^{67}$ Among others see RUBIO: Difusión (n. 1) 295-306; AlvAR (n. 52) 274; GORDON: Ritual (n. 52) 249. Clauss also addresses this matter, although on considering, as I have pointed out (see n. 52 above), that all the grades had a priestly character his approaches in this regard are somewhat contradictory: CLAUSS: The Roman Cult (n. 12) 138-140.

${ }^{68}$ CIMRM 249, 282, 511, 622, 626. The inscription in which there is a Pater next to two priests is even more eloquent: ibid. 313 .

${ }^{69}$ For a more detailed analysis on this theme, see RUBIO: Difusión (n. 1) 296-301.

${ }^{70}$ See n. 39 above.

${ }^{71}$ CLAUSS: The Roman Cult (n. 12) 43; GORDON: Ritual (n. 52) 251-257. In this respect one might wonder about the initiatic grade of the individual who dedicated the Ficulle's inscription (see $\mathrm{n}$. 11 above), recording the construction and dedication of a spelaeum along with all its sacred furniture, especially when, as I have already pointed out, it must have been a Mithraeum located inside his own villa.

72 The Egnatii were found amongst the magistrates of Carsulae, being one of the ruling families of the city: RosCINI, E.: Nuove epigrafi da Carsulae (Regio VI - Umbria). ZPE 189 (2014) 287-292, here 287

${ }^{73}$ On the connotations of the term consummati in this context: CIOTTI (n. 31) 243; RUBIO: Difusión (n. 1) 287-289 and 302. 
mentioned inscription of Montoro ${ }^{74}$ the same person appears as a sacerdos probatus who funded the reconstruction of a spelaeum destroyed by an earthquake, so that he undertakes a euergetic action proper of a Pater, as evidenced in the case of Ocriculum.

Lastly, a sacerdos is registered in one of the inscriptions from Sentinum, ${ }^{75}$ to which again a qualifier is added, on this occasion prosedens. In this case, the term seems to allude to presiding over an act: ${ }^{76}$ the dedication of a simulacrum by two devotees. It should be noted that the last line of the cultores collegial inscription mentions the menesterium that T. Sevius Felix would perform, which could have consisted of sacerdotal responsibilities or have been linked to collegial responsibilities. Precisely in the case of the numerous Mithraic community of Sentinum, a certain exclusivity of some families - like the Propertii and the Sevii - in accessing particular sacerdotal responsibilities can be noticed. ${ }^{77}$

This whole set of evidence confirms the relevance of Mithraism in Etruria and Umbria, in a period ranging from the early 2 nd century up to the end of the 4th century $\mathrm{AD}{ }^{78}$ The specificity of some attested features of this cult could be explained by its proximity to Rome and by the fluid communication existing along an extensive road network which crossed these territories, but also with an active diffusion whose specific reasons we do not know, and that provided the dimension and intensity which the Mithras cult obtained in these regions.

Rebeca Rubio Rivera

Universidad de Castilla-La Mancha

Facultad de Humanidades de Toledo

Spain

rebeca.rubio@uclm.es

${ }^{74}$ See n. 31 above.

${ }^{75}$ CIL XI 5736; CuMONT: $M M M$ II 120-121, 156; CIMRM 687. This inscription refers to the dating, corresponding to the year 219 AD.

${ }^{76}$ RUBIO: Difusión (n. 1) 303-305; RUBIO: Consideraciones (n. 2) 411.

${ }^{77}$ RUBIO: Difusión (n. 1) 305; RUBIO: Consideraciones (n. 2) 412.

${ }^{78}$ RUBIO: Difusión (n. 1) 225-227. 
